\title{
Margaret McCartney: Charities should respect evidence
}

\author{
Margaret McCartney general practitioner
}

Glasgow

Being well off and well connected is no barrier to a belief in nonsense. In fact, the more money you have, the easier it seems for healthcare professionals to liberate you from it.

Justin Trudeau, Canada's premier, created a new science post at cabinet level and is willing to explain quantum computing to a press pack. ${ }^{1}$ But even he undergoes cupping, ${ }^{2}$ an evidence-free complementary therapy used by self styled lifestyle gurus such as Gwyneth Paltrow. ${ }^{3}$ Reading systematic reviews, I despair at the lack of adequate evidence for this intervention. ${ }^{4}$

A recent supplement in the Financial Times reported on the Lanserhof medical spa in Austria, where a week's stay costs over $€ 3000$ ( $£ 2660$ ) for one person in the "basic" programme. The spa was described as a feast of "detoxing" with intravenous drips "to help me 'de-acidify,' which alongside bowel work is the big game play here."

Clients have abdominal ultrasound and undergo "bioenergetic diagnosis," which helps to "localise dissonances in your energy field and resolve them through bioenergetic intervention and regulation." Other interventions include being wrapped in goat butter. $^{5}$

We could argue that allowing people to fritter their money away helps redress health inequalities if the tax they pay on such treatment funds healthcare for others. But it also exposes them to risk of harm, profits people selling quackery, and allows a societal acceptance that this sort of thing is somehow aspirational and $\mathrm{OK}$.

When organisations promote non-evidence based interventions they may actively harm citizens. When charities do this the potential harm is even greater

What about believing in statements and advice from health charities? "Charity" is a word associated with goodness, selflessness, and altruism. But it should also be evidence based, because otherwise we risk needless harms.

When organisations promote non-evidence based interventions they may end up actively harming citizens. When charities do this the potential harm is even greater: "charity" evokes trustworthiness, not scepticism. The Homeopathy Action Trust agenda and Yes to Life promote complementary medicine. ${ }^{67}$. So do many more. ${ }^{8}$

Charities-which benefit from Gift Aid and get tax breaks-are meant to act "for the public benefit": the Charities Commission says that this can include "complementary, alternative, or holistic methods" and refers to a House of Lords report from 2000, ${ }^{10}$ but this report can't be expected to provide a definitive guide to evidence based medicine.

The commission recently consulted on its approach to deciding whether an organisation that uses or promotes complementary therapies is a charity. Currently, the commission says that publication of a peer reviewed study is suitable evidence; but, given the problems with the reliability of peer review and of cherry picking evidence, this isn't enough to protect the public or to deserve our trust.

Let's hope that charities are made to respect the evidence-and that leaders such as Trudeau follow shortly.

Competing interests: See www.bmj.com/about-bmj/freelancecontributors/margaret-mccartney.

Provenance and peer review: Commissioned; not externally peer reviewed.

Follow Margaret on Twitter, @mgtmccartney

1 Kakaes K. Actually, Justin Trudeau doesn't get quantum computing. Washington Post 18 April 2016. https://www.washingtonpost.com/posteverything/wp/2016/04/18/actually-justintrudeau-doesnt-get-quantum-computing/?utm term=.c60d1d29dbd4 .

2 MacDougall A. Why are we talking about cupping and the Prime Minister? Globe and Mail 25 April 2017. www.theglobeandmail.com/opinion/why-are-we-talking-about-cupping-andthe-prime-minister/article34804855/.

3 Roberts M. What caused Gwyneth's spots? BBC News 9 July 2004. http://news.bbc.co. uk/1/hi/health/3879447.stm.

$4 \mathrm{Cao} \mathrm{H}$, Li X, Liu J. An updated review of the efficacy of cupping therapy. PLoS One 2012;358:e31793, https://dx.doi.org/10.1371\%2Fjournal.pone.0031793. doi:10.1371/ journal.pone. 0031793 pmid:22389674.

5 Theron I. How to find it-the ultimate vitality spa break. Financial Times 6 May 2017. Homeopathy Action Trust. https://homeopathyactiontrust.org/.

7 Yes to Life: Your Options for Cancer. yestolife.org.uk; http://yestolife.org.uk/therapy display/Vitamin_C_Therapy.htm|\#.WRg3zFLMyuU.

8 Marshall M. Should complementary and alternative medicine charities lose their charitable status? Guardian 12 May 2017. https://www.theguardian.com/science/blog/2017/may/12/ cam-charities-must-back-up-medical-claims-or-lose-their-charitable-status-michaelmarshall.

9 Charity Commission for England and Wales. Guidance: charitable purposes. 16 Sept 2013. https://www.gov.uk/government/publications/charitable-purposes/charitablepurposes. 
10 House of Lords Select Committee. Science and technology — sixth report. 12 Nov 2000. https://www.publications.parliament.uk/pa/ld199900/ldselect/ldsctech/123/12301.htm.
Published by the BMJ Publishing Group Limited. For permission to use (where not already granted under a licence) please go to http://group.bmj.com/group/rights-licensing/ permissions 